\title{
PENGARUH SISTEM AKUNTANSI MANAJEMEN TERHADAP MANAJEMEN KUALITAS PROSES PADA PT.TELKOMSEL DISTRIBUTION CENTER MANADO
}

\author{
Maria Natalia Worotikan ${ }^{1}$, Jenny Morasa ${ }^{2}$, Sherly Pinatik ${ }^{3}$ \\ ${ }^{1,2,3}$ Jurusan Akuntansi, Fakultas Ekonomi dan Bisnis, Universitas Sam Ratulangi, Jl. Kampus Unsrat, Manado, \\ 95115, Indonesia
}

E-mail : mariaworotikan13@gmail.com

\begin{abstract}
Management accounting systems need to be implemented in a company to provide a basis for making business decisions so that management can be better prepared to manage and carry out the control functions. The purpose of this study is to analyze the effect of management accounting systems on quality management processes at PT. Telkomsel Distribution Center. The type of this study is quantitative research. The location of this study is Telkomsel Distribution Center Manado which is in form of survey with distributing questionnaires that had been prepared previously to conduct research. The population and sample are all employees at the Telkomsel Distribution Center Manado with 40 respondents. Retrieval of data using saturated samples. Data analysis using simple regression with hypothesis testing. The results of the study are on relationship model between management accounting systems and process quality management. There is a positive and significant relationship of management accounting systems to the management of process quality. The suggestion is that in an effort to improve management of process quality, management should improve management accounting systems of the company. The higher management accounting system the better it improve process quality management of Manado Telkomsel Distribution Center. Keywords: management accounting systems; process quality management
\end{abstract}

\section{PENDAHULUAN}

Perkembangan dunia bisnis di Indonesia sudah semakin melaju dengan cepat. Hal ini menyebabkan semakin ketat pula persaingan antar perusahaan yang membuat para pengusaha terpacu untuk mengelola perusahaan dengan lebih efektif dan efisien. Perusahaan merupakan suatu kegiatan yang dilakukan seseorang maupun organisasi yang tujuannya semata-mata untuk memperoleh keuntungan maksimal. Kegiatan itu dilakukan untuk memenuhi kebutuhan manusia yang semakin hari semakin meningkat sehingga keuntungan yang maksimal merupakan sebuah tujuan yang harus dicapai (Supriyono, 1992:153).

Sistem akuntansi manajemen disusun terutama untuk menghasilkan informasi yang berguna bagi pengambil keputusan atau manajemen. Biasanya informasi yang digunakan oleh manajemen berkisar pada biaya, sehingga juga bisa disebut dengan akuntansi biaya. Selain data biaya untuk harga pokok, akuntansi manajemen juga membutuhkan data untuk pengawasan dan analisis biaya yang dibuat dalam bentuk standar dan lain-lainnya. Perusahaan mendesain sistem akuntansi manajemen untuk membantu organisasi yang bersangkutan melalui para manajernya, yaitu dalam perencanaan, pengorganisasian, pengarahan dan pengambilan keputusan. Untuk membantu aktivitasnya, para manajer membutuhkan dukungan informasi (Halim, et al., 2014:3). Sistem akuntansi manajemen sebagai variabel kontekstual dinilai dapat mempengaruhi hubungan manajemen kualitas proses dan kinerja kualitas produk. Jadi, dalam hubungan ketiga variabel tersebut sistem akuntansi manajemen lebih tepat difungsikan sebagai variabel moderating. Konsumen yang merasa puas terhadap suatu produk pasti akan melakukan pembelian kembali terhadap 
produk tersebut sehingga memberikan dampak positif bagi suatu perusahaan. Perusahaan akan mendapat kepercayaan dari masyarakat dan kemenangan dalam persaingan.

PT. Telkomsel Distribution Center Manado merupakan tempat distribusi produk Telkomsel yang cukup besar di Manado antara lain produk pascabayar, simpati, kartu AS, MKIOS, dan produk-produk Telkomsel lainnya. Perusahaan ini lebih mengutamakan kepercayaan dan kepuasan konsumen dalam penjualan produk untuk meningkatkan daya saing. Maka dari itu perusahaan harus mencapai hasil yang baik, perusahaan menerapkan sistem akuntansi manajemen untuk memberikan dasar pembuatan keputusan bisnis sehingga manajemen bisa lebih siap untuk mengelola dan melakukan fungsi pengontrolan serta membutuhkan tingkat penjualan produk yang baik dalam manajemen kualitas proses untuk menghadirkan produk yang berkualitas tinggi.

\section{TINJAUAN PUSTAKA}

Warren, et al. (2014:3) mengatakan bahwa secara umum, akuntansi dapat diartikan sebagai sistem informasi yang menyediakan laporan keuangan untuk para pemangku kepentingan mengenai aktivitas ekonomi dan kondisi perusahaan. Menurut America Institute of Certified Public Accountants (AICPA), akuntansi adalah proses pencatatan, penggolongan, peringkasan, dan penyajian secara sistematis dari transaksi-transaksi keuangan suatu badan usaha, serta penafsiran terhadap fungsinya. Akuntansi adalah sistem informasi yang bermanfaat untuk mengukur aktivitas bisnis pemrosesan data dan alat komunikasi bagi antara perusahaan dan pengambilan keputusan (Pontoh, 2013:1). Akuntansi adalah proses mengidentifikasi, mencatat dan mengkomunikasikan kejadian-kejadian ekonomi sebuah organisasi kepada pihak-pihak yang berkepentingan, kejadian-kejadian ekonomi tersebut akan disajikan dalam bentuk laporan keuangan (Windah, et al., 2017). Tujuan utama akuntansi adalah menyajikan informasi ekonomi dari suatu kesatuan ekonomi kepada pihakpihak yang berkepentingan. Kegiatan akuntansi meliputi identifikasi dan mengatur data yang relevan untuk suatu keputusan yang dibuat, memproses data yang bersangkutan kemudian menyusun laporan, mengkomunikasikan laporan kepada pemakai, dimana akuntansi adalah seni pencatatan, pengklasifikasian, dan pengikhtisaran transaksi dan peristiwa keuangan dengan cara tertentu dan dalam ukuran moneter, termasuk penafsiran atas hasil-hasilnya (Mogontha, et al., 2017).

Menurut Butarbutar et al. (2017), akuntansi manajemen mengidentifikasi, mengumpulkan, mengukur, mengklasifikasikan, dan melaporkan informasi yang bermanfaat bagi pengguna internal dalam merencanakan, mengendalikan, dan mengambil keputusan. Akuntansi manajemen berkaitan erat dengan masalah penyajian informasi yang diperlukan oleh manajemen pada suatu organisasi. Akuntansi manajemen yaitu proses pengidentifikasian, pengukuran, penghimpunan, penganalisaan, penyusunan, penafsiran dan pengkomunikasian informasi keuangan yang digunakan manajemen untuk merencanakan, mengevalusai, dan mengendalikan kegiatan usaha di dalam sebuah organisasi, serta untuk memastikan penggunaan dan akuntabilitas sumber daya yang tepat (Simamora, 2012:13). Menurut Chenhall dan Deigan (1986) dalam Laksamana dan Muslichah (2002), terdapat empat karakteristik informasi sistem akuntansi manajemen yaitu: (1) ruang lingkup (scope); (2) tepat waktu (timelines); (3) agregasi (aggregation); dan (4) integrasi (integration).

Menurut Hansen dan Mowen (1999), tujuan dari sistem akuntansi manajemen adalah: (1) menyediakan informasi yang digunakan dalam perhitungan biaya jasa, produk, dan tujuan lain yang diinginkan manajemen; (2) untuk menyediakan informasi yang digunakan dalam perencanaan, pengendalian, dan pengevaluasian; dan (3) menyediakan informasi yang berguna dalam pengambilan keputusan. Menurut Hansen dan Mowen (1999), manajemen kualitas memiliki arti sebagai tindakan mengawasai semua kegiatan dan tugas-tugas yang diperlukan untuk mempertahankan tingkat keunggulan yang diinginkan. Ini termasuk 
penentuan kebijakan mutu, menciptakan dan menerapkan perencanaan mutu dan jaminan dan kontrol kualitas dan peningkatan kualitas. Kualitas yang diawasi tidak hanya terbatas pada kualitas produk tetapi juga kualitas perusahaan secara keseluruhan, mulai dari kualitas karyawan yang dipekerjakan, bahkan hingga kualitas perusahaan dimata para konsumen. Manajemen Kualitas Proses merupakan salah satu fungsi dari Total Quality Management (TQM). Manajemen kualitas proses yaitu serangkaian proses untuk menghasilkan produk yang berkualitas. Keunggulan organisasi yang sudah menerapkan manajemen kualitas adalah dapat melakukan pengembangan konsep kualitas dengan pendekatan totalitas.

Missah et al. (2019) membuktikan bahwa informasi yang memiliki cakupan luas dan lebih lengkap serta tepat waktu dapat mendukung pengambilan keputusan dan inovasi dimasa datang. Wala et al. (2020) menemukan bahwa sistem informasi akuntansi manajemen terhadap pengendalian kualitas produk dapat membantu setiap divisi-divisi dalam menjalankan setiap kegiatan pada bagian masing-masing untuk menghasilkan produk yang memenuhi standar kualitas yang telah ditetapkan oleh perusahaan. Dasmasela et al. (2020) menemukan bahwa penerapan total quality management akan sangat berdampak bagi para pekerja dan kualitas produk yang dihasilkan.

\section{METODE PENELITIAN}

Jenis penelitian yang digunakan adalah penelitian kuantitatif dengan menggunakan alat bantu SPSS 23. Penelitian kuantitatif yaitu penelitian yang mengambil sampel dari suatu populasi dan memakai kuesioner sebagai alat atau instrumen untuk mengumpulkan data pokok (Augusty, 2011:19-20). Penelitian ini dilakukan guna memperoleh data yang objektif dan akurat sehingga penelitian ini dilakukan langsung di PT. Telkomsel Distribution Center yang beralamat di Jl. Piere Tendean, Titiwungan Utara, Sario, Kota Manado, Sulawesi Utara.

Sumber data yang diperlukan dalam penelitian ini adalah: (1) data primer yaitu data yang diperoleh langsung dari informasi melalui wawancara dan hasil-hasil yang diperoleh dari survey pengisian kuesioner oleh responden penelitian; dan (2) data sekunder yaitu data yang diperoleh secara tidak langsung, melalui jurnal ilmiah, literatur dan buku-buku yang berhubungan dengan masalah yang dihadapi.

Populasi merupakan kelompok yang menjadi perhatian peneliti untuk diteliti (Sekaran dan Bougie, 2010). Populasi untuk penelitian ini adalah pihak manajemen atau pimpinan dan karyawan di PT.Telkomsel Distribution Center. Menurut Arikunto (2010:109), sampel adalah sebagian atau wakil dari jumlah populasi yang diteliti. Sampel penelitian ini berjumlah 40 orang responden, dimana seluruh pihak manajemen atau pimpinan, karyawan bagian administrasi, dan SPV (supervasior) dijadikan sebagai responden penelitian. Sampel dalam penelitian ini adalah populasi dimana semua responden dijadikan sebagai sampel penelitian. Berbagai data yang dikumpulkan dalam penelitian ini dilakukan dengan metode penelitian lapangan (field research method) yaitu pengumpulan data dengan mengadakan penelitian observasi, kuesioner, dan wawancara.

Definisi operasional dan pengukuran variabel adalah penentuan konstruk sehingga menjadi variabel yang dapat diukur. Variabel adalah segala sesuatu yang dapat diberi berbagai macam nilai. Variabel dapat diukur dengan berbagai macam nilai tergantung pada konstruk yang diwakilinya, yang dapat berupa angka atau berupa atribut yang menggunakan ukuran atau skala dalam suatu penilaian (Sugiyono 2013b:98). Definisi operasional dari penelitian ini disajikan pada Tabel 1. 
Tabel 1. Definisi operasional dan pengukuran variabel

\begin{tabular}{clll}
\hline Variabel & \multicolumn{1}{c}{ Pengertian } & \multicolumn{1}{c}{ Indikator } & \multicolumn{1}{c}{ Sumber } \\
\hline Sistem Akuntansi & Sistem yang & -Ruang lingkup & Chenhall dan \\
Manajemen $\left(\mathrm{X}_{1}\right)$ & menghasilkan & -Tepat waktu & Deigan \\
& output dengan & -Agregasi & \\
& menggunakan & -Integrasi & \\
& input tertentu & & \\
& dan & & \\
& memprosesnya & & \\
& untuk & & \\
& mencapai & & Tjiptono \\
& tujuan & & \\
& manajemen & & \\
Manajemen Kualitas & Serangkaian & -Fokus kepada pelanggan \\
Proses $\left(\mathrm{Y}_{1}\right)$ & proses untuk & -Perbaikan terus menerus \\
& menghasilkan & -Pengembangan sistem & \\
& produk yang & -Partisipasi secara penuh & \\
& berkualitas & -Pengukuran kinerja & \\
& & &
\end{tabular}

Sumber:Data olahan, 2019

Metode Analisis yang digunakan dalam penelitian ini adalah analisis regresi sederhana untuk menguji pengaruh Sistem Akuntansi Manajemen (X) terhadap Manajemen Kualitas Proses (Y). Analisis regresi linear sederhana adalah sebuah metode pendekatan untuk pemodelan hubungan antara satu variabel dependen dan satu variabel independen. Menurut Sugiyono (2013a:407-408), bentuk umum dari regresi linear sederhana secara matematis adalah:

$$
\mathrm{Y}=\alpha+\beta_{1} \mathrm{X}_{1}+\varepsilon
$$

Sehingga dapat dijabarkan dimana $\mathrm{X}_{1}$ adalah sistem akuntansi manajemen, $\mathrm{Y}$ adalah manajemen kualitas proses, $\alpha$ adalah konstanta, $\beta_{1}$ adalah koefisien regresi untuk variabel bebas, dan $\varepsilon$ adalah standard error.

\section{HASIL PENELITIAN DAN PEMBAHASAN \\ 4.1. Hasil penelitian}

Mayoritas responden dalam penelitian ini yaitu adalah wanita sebanyak 26 responden atau $65 \%$ dari total responden, berusia antara 21-30 tahun sebanyak 15 responden atau 37,5\% dari total responden. Ini berarti bahwa responden dalam penelitian ini kebanyakan adalah wanita, berusia muda. Tabel 2 dan 3 merupakan hasil uji validitas dan uji reliabilitas kuesioner penelitian yang dijadikan sebagai pedoman mengukur tingkat variabel-variabel dalam penelitian ini. Tabel 2 menunjukkan kriteria pertanyaan-pertanyaan dalam kuesioner untuk masing-masing variabel adalah valid. Hal ini terlihat dari nilai rata-rata $r$ hitung yang diperoleh lebih tinggi dari pada nilai kritis (> CR) sebesar 0,30. 
Going Concern : Jurnal Riset Akuntansi 15(2), 2020, 185-192

Tabel 2. Uji validitas

\begin{tabular}{|c|c|c|c|c|}
\hline \multirow{2}{*}{ Variabel } & \multirow{2}{*}{ Indikator } & \multicolumn{3}{|c|}{ Correlation (r) } \\
\hline & & $\mathbf{R}$ & Sig & Explanation \\
\hline \multirow{4}{*}{ Sistem Akuntansi Manajemen (X) } & $\mathrm{X} 1.1$ & 0,834 & 0.000 & Valid \\
\hline & $\mathrm{X} 1.2$ & 0,959 & 0.000 & Valid \\
\hline & $\mathrm{X} 1.3$ & 0,959 & 0.000 & Valid \\
\hline & $\mathrm{X} 1.4$ & 0,856 & 0.000 & Valid \\
\hline \multirow{5}{*}{ Manajemen Kualitas Proses (Y) } & Y1.1 & 0,691 & 0.000 & Valid \\
\hline & Y1.2 & 0,941 & 0.000 & Valid \\
\hline & Y1.3 & 0,920 & 0.000 & Valid \\
\hline & Y1.4 & 0,888 & 0.000 & Valid \\
\hline & $\mathrm{Y} 1.5$ & 0,888 & 0.000 & Valid \\
\hline
\end{tabular}

Sumber: Data olahan, 2019

Tabel 3 menunjukkan bahwa nilai alpha cronbach untuk setiap pertanyaan lebih besar dari nilai kritis (>CR) yaitu 0,6 bahkan secara rata-rata nilainya di atas 0,8 maka dapat disimpulkan bahwa setiap pernyataan dikatakan reliable atau masuk dalam kriteria sangat reliabel.

Tabel 3. Uji reabilitas

\begin{tabular}{lcl}
\hline \multicolumn{1}{c}{ Variabel } & Alpha Cronbach & \multicolumn{1}{c}{ Kriteria } \\
\hline Sistem Akuntansi Manajemen $(X)$ & 0,910 & Sangat Reliabel \\
Manajemen Kualitas Proses $(Y)$ & 0,916 & Sangat Reliabel \\
\hline
\end{tabular}

Sumber: Data olahan, 2019

Untuk menentukan normal tidaknya data pada variabel dependen dilakukan dengan melihat grafik plot normal. Apabila data distribusi normal, maka penyebaran plot akan berada disepanjang garis $45^{\circ}$. Dari grafik plot normal (lampiran Gambar 1) dapat diketahui bahwa penyebaran plot berada di sepanjang garis $45^{\circ}$ sehingga dapat disimpulkan bahwa data terdistribusi secara normal.

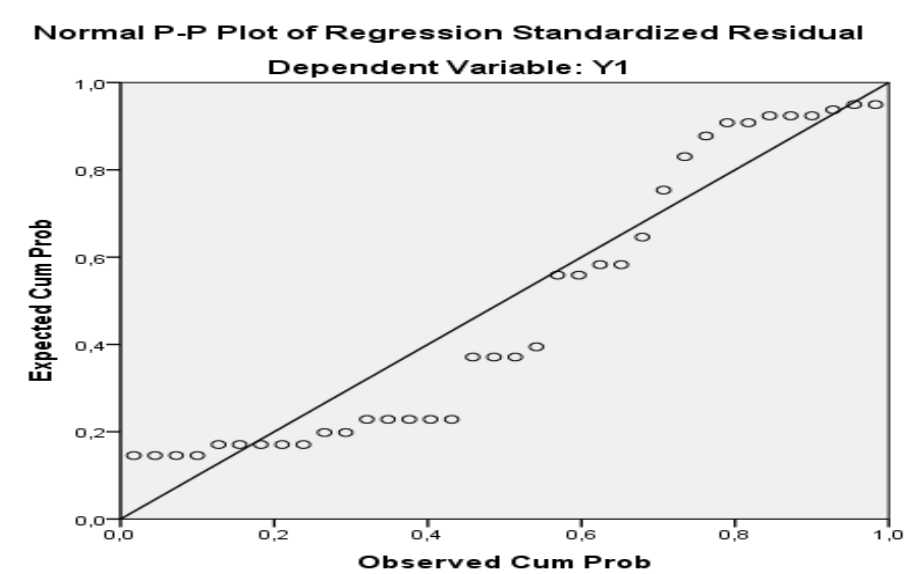

Gambar 1. Uji Normalitas

Sumber: Data olahan, 2019

Gambar 2 menunjukkan bahwa grafik Scatterplot yang ditampilkan untuk uji heterokesdastisitas menampakkan titik-titik yang menyebar secara acak dan tidak ada pola yang jelas terbentuk serta dalam penyebaran titik-titik tersebut menyebar dibawah dan diatas angka 0 pada sumbu Y. Hal tersebut mengidentifikasikan tidak terjadinya heterokesdastisitas 
pada model regresi, sehingga model regresi layak dipakai untuk memprediksi variabel Manajemen Kualitas Proses (Y).

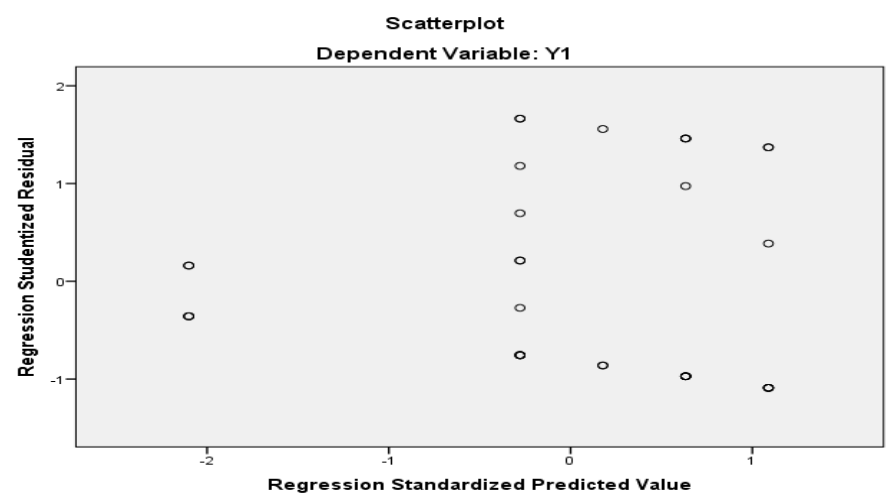

Gambar 2. Uji Heteroskedastisitas

Sumber: Data olahan, 2019

Berdasarkan hasil perhitungan dengan menggunakan bantuan program SPSS seperti yang ada pada Tabel 4 dapat dilihat bahwa nilai (R) yang dihasilkan adalah sebesar 0,225 artinya mempunyai hubungan yang cukup kuat. Nilai $\mathrm{R}$ square adalah 0,051 atau 5,1\% Artinya pengaruh variable bebas yaitu: Sistem Akuntansi Manajemen (X), terhadap variable independent Manajemen Kualitas Proses (Y) sebesar 5,1\% dan sisanya sebesar 0,949 atau 94,9\% dipengaruhi variable-variabel lain di luar model ini.

Tabel 4. Koefisien regresi sederhana uji $t$, uji f untuk hubungan sistem akuntansi manajemen $(x)$ terhadap manajemen kualitas proses $(y)$

\begin{tabular}{|c|c|c|c|c|}
\hline & Regression Coeef. (b) & Std Er & $\mathrm{t}$ (count) & Sig. \\
\hline Konstanta & 18,075 & 2,707 & 6,678 & 0,000 \\
\hline Sistem Akuntansi Manajemen & 0,218 & 0,162 & 2,348 & 0,000 \\
\hline $\mathrm{R}$ & $=$ & 0,225 & & \\
\hline R Square & $=$ & 0,051 & & \\
\hline F count & $=$ & 5,818 & & \\
\hline t table & $=$ & 2,008 & & \\
\hline Sig. F & $=$ & 0,000 & & \\
\hline $\mathrm{N}$ & $=$ & 40 & & \\
\hline$\alpha$ & $=$ & $0.05(5 \%)$ & & \\
\hline
\end{tabular}

Sumber: Data olahan, 2019

\subsection{Pembahasan}

1. Berdasarkan Tabel 4 dapat dilihat bahwa nilai variabel sistem akuntansi manajemen $t_{\text {hitung }}$ $=2,348>t_{\text {tabel }}=2,008$ dan tingkat signifikan sebesar $0,000<0,05$. Hal menunjukkan bahwa nilai signifikansi variabel ini lebih kecil dari 0,05. Seperti yang telah dijelaskan sebelumnya, hipotesis akan diterima jika nilai signifikansi kurang dari 0,05, maka dapat disimpulkan bahwa $\mathrm{H}_{\mathrm{a}}$ diterima dan $\mathrm{H}_{0}$ ditolak atau berarti Sistem Akuntansi Manajemen berpengaruh signifikan terhadap Manajemen Kualitas Proses.

2. Berdasarkan hasil uji statistik dapat dijelaskan bahwa manajemen kualitas proses dipengaruhi oleh sistem akuntansi manajemen, meskipun dalam model ini juga mengindikasikan adanya pengaruh dari variabel- variabel lain yang tidak diteliti dalam penelitian ini. Hasil pengujian model untuk regresi diperoleh sistem akuntansi manajemen (X) berpengaruh positif dan signifikan terhadap manajemen kualitas proses (Y), artinya 
apabila sistem akuntansi manajemen meningkat maka manajemen kualitas proses akan meningkat. Nilai (R) yang dihasilkan adalah sebesar 0,225 artinya mempunyai hubungan yang cukup kuat. Nilai R square adalah 0,051 atau 5,1\% Artinya pengaruh variabel bebas yaitu Sistem Akuntansi Manajemen (X), terhadap variabel independen Manajemen Kualitas Proses (Y) sebesar 5,1\% dan sisanya sebesar 0,949 atau 94,9\% dipengaruhi variabel-variabel lain di luar model ini.

3. Penggunaan sistem akuntansi manajemen ini berdampak baik terhadap manajemen kualitas proses. Hal ini terbukti dengan penelitian yang di lakukan pada PT. Telkomsel Distribution Manado. Dimana sistem akuntansi manajemen sudah mempengaruhi manajemen kualitas proses. Hasil penelitian ini memperkuat penelitian sebelumnya yaitu penelitian dari Wardani dan Ja'far (2009), dan Kurnia (2015), dimana yang menemukan bahwa sistem akuntansi manajemen berpengaruh terhadap manajemen kualitas proses. Hal ini menjadikan sistem akuntansi manajemen sebagai salah satu prediktor dari manajemen kualitas proses.

\section{KESIMPULAN DAN SARAN}

\subsection{Kesimpulan}

Berdasarkan hasil analisis dan pembahasan data, dapat disimpulkan bahwa sistem akuntansi manajemen berpengaruh terhadap manajemen kualitas proses. Terdapat hubungan yang positif dan signifikan dari sistem akuntansi manajemen terhadap manajemen kualitas proses dimana jika terjadi peningkatan atau kenaikan terhadap sistem akuntansi manajemen akan meningkatkan atau menaikan manajemen kualitas proses di PT. Telkomsel Distribution Center Manado sebaliknya jika terjadi penurunan terhadap sistem akuntansi manajemen akan menurunkan manajemen kualitas proses di PT. Telkomsel Distribution Center Manado.

\subsection{Saran}

Saran atas penelitian ini adalah bahwa hasil penelitian ini diharapkan dapat menambah wawasan pengetahuan terkait dengan hasil penelitian ini yaitu kaitan antara sistem akuntansi manajemen terhadap manajemen kualitas proses. Bagi manajemen Telkomsel Distribution Center Manado serta Telkomsel Distribution Center yang ada di mana saja, sebagai acuan dalam pengambilan kebijakan di masa yang akan datang. Dalam rangka meningkatkan manajemen kualitas proses, manajemen hendaknya meningkatkan sistem akuntansi manajemen di perusahaan dimana semakin tinggi sistem akuntansi manajemen akan semakin baik dalam meningkatkan manajemen kualitas proses dari Telkomsel Distribution Center Manado.

\section{DAFTAR PUSTAKA}

Arikunto, S. (2010). Prosedur penelitian: Suatu pendekatan praktik, Edisi revisi. Jakarta: PT. Rineka Cipta.

Augusty, F. (2011). Metode penelitian manajemen: Pedoman penelitian skripsi, tesis dan desertasi ilmu manajemen, Edisi kelima. Semarang: BP Undip.

Butarbutar, J. D., Karamoy, H., \& Tirayoh, V. Z. (2017). Analisis penerapan sistem akuntansi manajemen terhadap pengendalian kualitas produk di PT Empat Saudara Manado. Going Concern: Jurnal Riset Akuntansi, 12(1), 187-193. https://doi.org/10.32400/gc.12.01.17204.2017

Chenhall., R. H., \& Deigan, M. (1986). The impact of structure, environment, and interdependence on the perceived usefulness of management accounting system. The Accounting Review, 61(1), 16-35. http://www.jstor.org/stable/247520 
Dasmasela, V., Morasa, J., \& Rondonuwu, S. (2020). Penerapan Total Quality Management terhadap produk cacat pada PT. Sinar Pure Foods International di Bitung. Indonesia Accounting Journal, 2(2), 97-102. https://doi.org/10.32400/iaj.27796

Halim, A., Supomo, B., \& Kusufi, M. S. (2014). Akuntansi manajemen (akuntansi manajerial), Edisi kedua. Yogyakarta: Badan Penerbitan Fakultas Ekonomi BPFE.

Hansen, D. R., \& Mowen, M. M. (1999). Akuntansi manajemen, Edisi keempat. Jakarta: Penerbit Erlangga.

Kurnia, D. (2015). Analisis sistem akuntansi manajemen pada perusahaan manufaktur di Kabupaten Serang implikasinya pada kelangsungan hidup (going concern) perusahaan. Jurnal Akuntansi: Kajian Ilmiah Akuntansi, 2(1), 86-102. http://ejurnal.lppmunsera.org/index.php/Akuntansi/article/view/194

Laksamana, A., \& Muslichah. (2002). Pengaruh teknologi informasi, saling ketergantungan, karakteristik sistem akuntansi manajemen terhadap kinerja manajerial. Jurnal Akuntansi dan Keuangan, 4(2), 106-125. http://jurnalakuntansi.petra.ac.id/index.php/aku/article/view/15694

Missah, L., Ilat, V., \& Tirayoh, V. (2019). Pengaruh karakteristik informasi akuntansi manajemen terhadap kinerja manajerial pada PT. Bank Sulutgo. Indonesia Accounting Journal, 1(2), 39-44. https://doi.org/10.32400/iaj.26176

Mogontha, W., Nangoi, G. B., \& Gerungai, N. (2017). Analisis pengaruh aspek keperilakuan terhadap sistem akuntansi (studi kasus pada PT. Sinar Galesong Prima di Manado). Going Concern: Jurnal Riset Akuntansi, 12(2), 1055-1062. https://doi.org/10.32400/gc.12.2.18532.2017

Pontoh, W. (2013). Akuntansi: Konsep dan aplikasi. Jakarta: Halaman Moeka.

Sekaran, U., \& Bougie, R. (2010). Research methods for business: A skill building approach, 7th Edition. USA: John Wiley \& Son, Inc.

Simamora, H. (2012). Akuntansi manajemen, Edisi ketiga. Riau: Star Gate Publisher.

Sugiyono. (2013a). Metode penelitian bisnis. Bandung: CV Alfabeta.

Sugiyono. (2013b). Metode penelitian manajemen. Bandung: CV Alfabeta.

Supriyono, R. A. (1992). Akuntansi biaya: Perencanaan dan pengendalian biaya serta pembuatan keputusan, Edisi kedua. Yogyakarta: Badan Penerbitan Fakultas Ekonomi Yokyakarta.

Tjiptono, F. (2015). Strategi pemasaran, Edisi 4. Yogyakarta: Andi.

Wala, T., Nangoi, G., \& Walandouw, S. (2020). Penerapan sistem informasi akuntansi manajemen terhadap pengendalian kualitas produk pada Holland Bakery Manado. Indonesia Accounting Journal, 2(1), 58-65. https://doi.org/10.32400/iaj.27705

Wardani, B. K., \& Ja'far, M. S. (2009). Pengaruh sistem akuntansi manajemen terhadap hubungan manajemen kualitas proses dan kinerja kualitas produk. Jurnal dan Prosiding SNA-Simposium Nasional Akuntansi, 12, 1-21. http://pdeb.fe.ui.ac.id/?p=6211

Warren, C. S., Reeve, J. M., Duchac, J. E., Suhardianto, N., Kalanjati, D. S., Jusuf, A. A., \& Djakman, D. C. (2014). Pengantar akuntansi: Adaptasi Indonesia, Edisi satu. Jakarta: Salemba Empat.

Windah, N. M., Karamoy, H., \& Suwetja, I. G. (2018). Analisis kepatuhan penerapan akuntansi persediaan pada PT. Makassar Mandiri Putra Utama (Beta Berlian) Manado. Going Concern: Jurnal Riset Akuntansi, 13(2), 610-619. https://doi.org/10.32400/gc.13.02.19920.2018 